ДЕМИДОВА Елена Игоревна - доктор исторических наук, профессор, заведующий кафедрой истории, философии, политологии и социологии Саратовского социально-экономического института - филиала Российского экономического университета им. Г.В. Плеханова (410003, Россия, 2. Саратов, ул. Радищева, 89; demidova-elena@yandex.ru)

НАУМОВ Сергей Юрьевич - доктор исторических наук, профессор, директор Саратовского социально-экономического института - филиала Российского экономического университета им. Г.В. Плеханова (410003, Россия, г. Саратов, ул. Радищева, 89; rector@seun.ru)

ЗАХАРОВ Александр Викторович - доктор исторических наук, профессор кафедры истории, философии, политологии и социологии Саратовского социально-экономического института филиала Российского экономического университета им. Г.В. Плеханова (410003, Россия, г. Саратов, ул. Радищева, 89; ZaharovAV2007@yandex.ru)

ЕФИМОВА Елена Александровна - кандидат исторических наук, доцент кафедры истории, философии, политологии и социологии Саратовского социально-экономического института филиала Российского экономического университета им. Г.В. Плеханова (410003, Россия, г. Саратов, ул. Радищева, 89; helenn79@таil.ru)

\title{
ГУМАНИЗМ И ПАТРИОТИЗМ КАК ФАКТОРЫ КОНСОЛИДАЦИИ РОССИЙСКОГО ОБЩЕСТВА В ГОДЫ ПЕРВОЙ МИРОВОЙ ВОЙНЫ
}

Аннотация. Статья посвящена проблеме взаимодействия государственной власти и общества в годы Первой мировой войны. Авторы рассматривают формы проявления российского патриотизма и гуманизма, а также роль государственных и общественных структур в создании атмосферы единения и согласия, свойственной начальному периоду войны. Сделан вывод, что ментальные традиции формировали у различных групп населения потребность не только в совершении подвига на фронте и в тылу, но также в общественно-полезной и благотворительной деятельности.

Ключевые слова: гуманизм, патриотизм, Первая мировая война, консолидация общества, благотворительность

Ю билейная дата - 100-летие со дня начала Первой мировой войны - дала историкам существенный информационный повод переосмыслить историю этой войны, которая во многом и для многих продолжает оставаться неизвестной войной. Любая война, а тем более война на собственной территории, всегда оказывает сильнейшее влияние на все стороны жизни общества, которое мобилизует весь свой экономический, военный, а главное - человеческий потенциал для защиты своего Отечества. И здесь, на наш взгляд, особое значение имеют не столько мобилизационные возможности государства, сколько социокультурные факторы, определяющие «качество» населения. Именно человек является главным на войне - от его восприятия событий и отношения к ним, от социокультурных ценностных ориентиров, морального самочувствия во многом зависит исход войны. История знает немало примеров, когда не самая сильная в военном отношении армия в условиях патриотического подъема и при широкой поддержке со стороны гражданского населения достигала впечатляющих успехов на фронтах войны. Моральный дух зависит как от ментальных черт самого населения (воинственность, миролюбие, гуманизм), так и от общей обстановки в стране, от взаимоотношений власти и общества, а также от историко-культурных традиций и идеологической пропаганды.

В этом отношении обращение к многогранной проблеме проявления патриотизма и гуманизма в обществе в условиях Первой мировой войны является необходимым для формирования целостной картины происходивших 100 лет 
назад событий. Важно это и для понимания причин трансформации настроений населения - от полной поддержки власти по вопросу вступления в войну до негативного отношения, послужившего одной из предпосылок революционного подъема в 1917 г.

История Первой мировой войны на протяжении почти всего XX в. была примером стереотипов и односторонних подходов в отечественной истории. Причиной этого стало позиционирование ее в советской историографии исключительно как империалистической, что стало основой весьма упрощенного взгляда на историю этих трагических событий. Так, известный ученый этой эпохи М.Н. Покровский и его последователи считали, что именно российский царизм был главным виновником развязывания мирового конфликта. При этом они не слишком вникали во все сложности геополитической обстановки в мире, не принимали во внимание ни возросшую агрессивность Германской империи, ни экспансию на Балканах со стороны Австро-Венгрии. Влияние М.Н. Покровского на академическую науку и образование негативно сказалось на объективности изучения российской истории периода Первой мировой войны. В течение длительного времени его точка зрения была концепционной для других ученых. В начале 1990-х гг. произошли существенные изменения в изучении истории Первой мировой войны. Стали доступными многие архивные документы, эмигрантская литература, началось переосмысление старых концепций. В результате появились обобщающие научные исследования по наиболее значимым аспектам Первой мировой войны, отличающиеся тематической новизной, отсутствием идеологической ангажированности, объективностью, широкой доказательной аргументацией. Экономические, миграционные и социальные аспекты на примерах различных российских регионов были освещены в работах И.Б. Беловой, Е.К. Максимова и В.П. Тофталушина, А.Н. Грицаевой [Белова 2011; Максимов, Тофталушин 2007; Грицаева 2008] и др., которые сделали вывод, что война стала тяжелым испытанием для населения страны. Сформировалась дискуссия специалистов по проблеме эволюции общественного сознания, что позволило достичь определенного плюрализма мнений. Так, современная историография еще не дала четкого ответа на вопрос об отношении населения к военнопленным. Историки приводят прямо противоположные точки зрения - от полной ненависти к врагу до проявления гуманности и даже доброжелательности [Белова 2007; Ефимова, Захаров 2014].

Одним из ключевых вопросов современной российской историографии Первой мировой войны стала проблема беженцев, анализ которой прослеживается в трудах М.В. Васильева и Е.Ю. Семеновой [Васильев 2014; Семенова 2014]. Исследователей интересуют не столько обстоятельства прибытия беженцев в тыловые районы страны и их обустройство на новом месте, сколько взаимоотношения их с местными жителями. Здесь также не сложилась единая точка зрения. Одни историки выдвигают аргументы в пользу милосердия, сопереживания населения к прибывшим и искреннего желания помочь, другие же приводят доказательства негативного отношения из-за обострившихся по причине перенаселенности социальных конфликтов. Не менее интересной темой исследования стало восприятие войны различными социальными группами общества и эволюция взглядов на войну [Холодов 2010; Поршнева 2000]. Особенно актуальными являются региональные исследования, позволяющие понять особенности мировоззрения населения центральных и отдаленных регионов страны, а также показать влияние объективных факторов на патриотические и гуманистические настроения в обществе.

На наш взгляд, именно патриотизм и гуманизм являлись главными условиями консолидации общества вокруг единой цели - отстоять интересы России 
и защитить свою территорию. Важность достижения гражданского согласия осознавалась политическим руководством страны еще задолго до начала войны. Идеи патриотизма, национального единства должны были направлять народ на борьбу с внешним врагом. Поэтому не случайно, что уже в первые дни войны она была официально провозглашена второй Отечественной, а население воспринимало ее как оборонительную и справедливую.

Одним из главных критериев подъема национальных чувств стала мобилизация населения на фронт, которая продемонстрировала практически полное отсутствие уклонений от службы. Патриотический подъем носил естественный характер и охватил почти всю Россию, что оказало огромное влияние на развитие военных действий в первые месяцы войны. Наиболее мощный патриотический порыв показало крестьянство. По нашему мнению, сельское население, большей частью неграмотное, было далеко от политики, зачастую не понимало и не осознавало, что защищает в этой войне братьев-славян или геополитические интересы своего государства. А волна патриотизма и самопожертвования, которые не в меньшей степени, чем в годы Великой Отечественной войны, наблюдались как на фронте, так и в тылу, были вызваны не столько стремлением защитить Отечество, сколько любой ценой сохранить свою собственную землю, ту, которая кормила их семьи. Кроме того, в годы войны энтузиазм крестьян подогревался и надеждами на разрешение аграрного вопроса в их пользу и на их условиях.

Не осталась в стороне и учащаяся молодежь. Из Саратовского университета были призваны на действительную военную службу 6 вольнонаемных писцов канцелярий и 26 низших служащих, в качестве врачей - 2 лица, исполнявших обязанности ассистентов клиник ${ }^{1}$. На фронт отправились ведущие профессора - хирурги Б.А. Арапов, С.Р. Миротворцев, В.И. Разумовский и др. Всего с 1914 по 1916 г. из СГУ были призваны на военную службу до 30 лиц младшего учебно-медицинского персонала².

Немало желающих пойти на фронт оказалось и среди женщин. Это были представительницы различных социальных слоев, возраста, национальности, вероисповедания и уровня образования. Некоторые женщины желали разделить тяготы войны с близкими людьми и уходили на фронт вслед за мужьями, сыновьями. Но большинством все же двигал патриотический настрой. Массовый характер принял набор девушек и женщин в сестры милосердия. Так, только в одном Саратове к концу июля 1914 г. такое желание изъявили свыше 100 чел. [Семьянинов 1914]. Взваливая на свои плечи порой непосильную ношу, женщины с особым рвением пытались заменить на производстве мужчин, ушедших на фронт. Они соглашались даже на самые тяжелые работы, например на землечерпательные работы на Волге, где в основном использовался труд заключенных.

В результате массовой мобилизации крестьян, а также постоянных реквизиций скота для нужд русской армии были значительно подорваны производительные силы деревни. В наиболее тяжелом положении оказались домохозяйства, оставшиеся без кормильца. Уже в первые месяцы войны с целью оказания помощи таким семьям многие сельские общества в уездах Саратовской губернии брали их под свою опеку. Так, по «приговору мира» вдовьим семьям производили вспашку земельных наделов, выделяли семена, помогали убрать урожай. В зимнее время для тех семей, где мужчины ушли на фронт или погибли на

\footnotetext{
1 ГАСО. Ф. 393. ОП.1. Д. 458. Л. 20.

2 Отчет о состоянии и деятельности Императорского Николаевского университета за 1916 год . ИСУ. 1917. Т. 8. Вып. 1/2. С. 6.
} 
фронте, крестьяне заготавливали дрова, организовывали подвоз сена и соломы. Помимо этого, в годы Первой мировой войны сельские общества неоднократно проводили сбор пожертвований семьям солдаток и вдов.

Взаимопомощь была распространена не только в крестьянской среде. Так, адвокатское содружество Петрограда, понимая трудности женщин и детей, оставшихся без кормильцев, организовало ежемесячный сбор пожертвований в пользу семей присяжных поверенных и их помощников, ушедших на фронт, в размере от 1 до 3 руб. с каждого. Эти средства позволили выделить каждой семье пособие в размере в среднем 100 руб. Подобную материальную помощь оказывали и семьям московских, саратовских, киевских адвокатов ${ }^{1}$.

На призыв о помощи отозвались и деятели искусства. В 1915 г. во флигеле Аничкова дворца была устроена выставка и распродажа работ фарфорового и стеклянного заводов в пользу лазарета при заводах. Среди работ встречались произведения скульпторов К.А. Сомова, С.Н. Судьбинина, А.Л. Обера, В.В. Кузнецова. Общество им. А.И. Куинджи провело аукцион, где, кроме произведений членов общества и многих других художников, поступили в продажу работы И.Я. Репина и В.М. Васнецова. Вырученные средства направлялись на поддержку раненых, часть сбора шла в пользу лазарета деятелей искусства. И.Я. Репин договорился с комитетом выставки этюдов, эскизов и рисунков товарищества передвижных выставок о том, что в случае продажи его работ половина средств должна была отправлена на помощь населению Бельгии, пострадавшему от австро-германских войск ${ }^{2}$.

Посильная помощь осуществлялась не только семьям призванных на фронт, но и оказавшихся в плену. При Московском городском общественном управлении активно работал Комитет помощи русским военнопленным и застигнутым войной за границей. Сотрудники этой организации взяли на себя пересылку писем военнопленных, а также оказание материальной помощи, в т.ч. закупку необходимых военнопленным предметов и отправку их через нейтральные страны.

Комитет обратился к земствам с посланием, в котором указывалось на неудовлетворительное положение русских военнопленных во вражеских странах, а также содержался призыв о помощи ${ }^{3}$. Воззвание в короткий срок помогло организовать общественность на решение этой проблемы. Население с большим энтузиазмом жертвовало не только денежные средства, но и товары первой необходимости - продукты питания, постельные принадлежности, табак и т.д. Так, Астраханское уездное земство собрало в 1916 г. 1000 руб. на оказание помощи русским военнопленным, находящимся во вражеских странах 4 . Благодаря деятельности Комитета помощи русским военнопленным и установлению близкого сотрудничества с Датским Обществом Красного Креста, отправляемая гуманитарная помощь достигала адресатов и справедливо распределялась между военнопленными. Подобная инициатива существенно облегчала крайне тяжелое положение наших граждан в плену.

Следует отметить, что россияне демонстрировали весьма гуманное отношение к военнопленным. Конечно, оно зависело от национальности пленных и варьировалось - от сочувствия к славянам, снисходительности к австрийцам до недружелюбия к немцам. Обострение враждебности возникало лишь после известий о беспощадности противника на фронтах или жестоком обращении в

\footnotetext{
1 Война и адвокатура. - Право. 1914. № 34(11). С. 2489.

2 Аполлон. 1915. № 1. С. 65; № 10. С. 55; 1916. № 1. С. 34; 1916. № 2. С. 36-37.

3 Журналы 3-го очередного астраханского уездного земского собрания. 10-21 ноября 1915 г. Астрахань. 1916. С. 142-144.

4 Там же. С. $49,52$.
} 
австрийском и немецком плену. Но, как правило, все обходилось без агрессии и ограничивалось возмущением жителей слишком, по их мнению, заботливым отношением власти к попавшим в плен немцам [Белова 2007: 42-44].

30 октября 1914 г. было создано Всероссийское попечительство о пленных славянах, отделения которого были открыты во многих городах России, в т.ч. и в Поволжье. Попечительство на собранные пожертвования обеспечивало пленных денежными пособиями, продуктами, одеждой, табачными изделиями, подарками к праздникам. Тот, кто нуждался во врачебной помощи, получал ее в полном объеме в лазаретах вместе с русскими солдатами. Имеются сведения, указывающие на весьма заботливое отношение к бывшим солдатам противника, - им выделялись лучшие помещения в лечебных учреждениях, кровати с пружинами, качественное белье, т.е. то, чего своим русским солдатам не всегда хватало.

Еще одним проявлением гуманизма стала забота о беженцах. Массовая миграция населения из прифронтовых районов началась уже в первые месяцы войны. Однако наибольшего размаха этот процесс достиг к концу 1915 г., когда в центральных губерниях скопилось около 3 млн чел. Тысячи людей были вынуждены оставить свои дома и имущество и искать спасения в тылу. В Саратовской губернии в октябре 1915 г. насчитывалось уже более 100 тыс. чел.. На совещании председателей земских управ Саратовской губернии был выработан общий губернский план мероприятий по оказанию помощи беженцам. За счет финансовых средств, выделенных государственными, местными органами власти и благотворительными организациями, был создан фонд в размере 1,3 млн руб., но этой суммы явно не хватало, особенно с учетом того, что среди беженцев было много больных, в т.ч. холерой. По этой причине требовались дополнительные расходы на лечение. Из фонда помощи беженцам выделялось по 7,5 руб. в месяц на каждого. Помимо этого, 70 тыс. руб. были направлены на постройку бараков в городах Балашове и Ртищево, но и это не смогло существенно решить жилищный вопрос. Местная власть оказалась не готовой к такому огромному потоку спасающегося от войны населения. Некоторые гласные земских управ были вынуждены поселять беженцев в своих домах. В сельской местности беженцев размещали в крестьянских семьях. Первоначально отношение местного населения к беженцам было весьма сочувственным - рабочие и крестьяне делили с ними не только жилье, но и питание. В местах их компактного расселения создавались специальные школы для детей, приюты для оставшихся без попечения родителей.

Местная власть тыловых губерний видела в беженцах и определенный трудовой потенциал. Привлечение переселенцев к сельскохозяйственным работам было вызвано необходимостью восполнить убыль мужского населения, а также возможностью экономии средств на их содержание. Однако попытка эффективного использования труда беженцев в народном хозяйстве не увенчалась успехом. Во-первых, основным контингентом миграционных потоков внутрь страны являлись женщины, дети, старики, чей трудовой потенциал был невысок. Во-вторых, несмотря на то, что расценки на проведение сельскохозяйственных работ беженцами были несколько выше, чем для местного населения, большинство трудоспособных беженцев различными способами уклонялись от работ, т.к. имели регулярное государственное довольствие. Со временем такая ситуация стала все чаще вызывать недовольство местных крестьян. Отметим, что так или иначе, но ситуация с беженцами стала в определенной степени причиной раскола, дезинтеграции сельской среды, что, в конечном итоге, сказалось на нарастании ситуации всеобщей крестьянской смуты в России. 
Первая мировая война на начальном этапе консолидировала все общество вокруг решения насущных проблем, и в первую очередь - оказания гуманитарной помощи нуждающимся. Мобилизация усилий властных структур, учреждений, общественных организаций и обычных граждан позволила реализовать множество практик, направленных на адаптацию гражданского населения к тяготам войны.

В годы Первой мировой войны возросла социальная роль Русской православной церкви, что можно проследить на многочисленных примерах деятельности духовных лиц и организаций. Так, Самарская епархиальная комиссия 25 ноября 1914 г. в ответ на сообщение бывшего воспитанника Самарской духовной семинарии А.В. Розова, офицера действующей армии, о нужде его роты в теплой одежде приняла решение о необходимости сбора и посылки всего необходимого на адрес ротного командира. Среди тех, кто собирал подарки, были жители Николаевского уезда: жена священника с. Сакма Мария Образцова, жена псаломщика с. Малая Тарасовка Александра Кастровская, протоирей с. Березовый Яр о. Гавриил Войтов. Кроме того, комиссия по пожертвованиям заготавливала и отсылала в действующую армию посылки, приуроченные к различным праздникам. Например, к Пасхе было собрано подарков на сумму 1500 рублей для 100 нижних чинов. В пасхальный набор входили: крестик, Евангелие, сапоги, рубаха, кальсоны, шило, дратва, нитки, пять иголок, гребешок, карандаш, 6 листов бумаги, 6 конвертов, ножичек, трубка, ложка, 1/4 ф. табака, 1 ф. мыла, 1/8 ф. чая, 1 ф. сахара, 1 ф. изюма, 1 ф. соли, 1 копченая сельдь, 6 баранок, $1 / 2$ ф. колбасы и 2 красных яичка. К Рождеству 1916 г. в войска было отправлено подарков на сумму 4800 рублей. Всего в кассу епархиальной комиссии со дня открытия и до 1 января 1916 г. поступило 86715 руб. 40 коп. и из личных средств духовенства -80000 руб., не считая вещей ${ }^{1}$.

Атмосфера патриотического подъема затронула все социальные группы населения, в первые месяцы войны даже оппозиционные силы действовали как часть гражданского социума, охваченного единой национальной идеей отстоять интересы Отечества. Не остались в стороне и немцы-колонисты, считавшие к этому времени Россию родной страной. Особого размаха благотворительность российских немцев достигла в Саратовской губернии, где достаточно организованно проходил сбор пожертвований, одежды, продовольствия для фронта. Причем помощь исходила как от целых немецких поселений, так и от общественных организаций и отдельных лиц. На средства, собранные российскими немцами, открывались лазареты, в которых самоотверженно трудились в т.ч. и врачи-немцы. Несмотря на активное участие немцев-колонистов в оказании помощи солдатам, раненым, беженцам, их заслуги не были по достоинству оценены обществом. Начиная с 1915 г. происходило заметное ухудшение отношения населения к ним. Жителям немецких колоний запрещались любого рода общественные собрания, за исключением богослужения, а также употребление немецкого языка в общественных местах. Второй запрет принес большие неудобства, особенно тем, кто относился к старшему поколению. Так, пострадали трое жителей с. Сарепты Царицынского уезда Саратовской губернии за то, что говорили по-немецки в общественных местах. Один отделался штрафом, другой был посажен под арест на 8 суток. Третьего обвинили не только в употреблении немецкого языка, но и в оскорблении его величества [Медведев 2014].

Часто звучали обвинения в адрес немцев как в сочувствии к противнику, так и в открытом шпионаже в пользу Германии. Не последнюю роль в этом сыграла официальная позиция центральной власти, а также и навязывание прессой

\footnotetext{
${ }^{1}$ Самарские Епархиальные ведомости. 1914. № 2. С. 554; 1916. № 2. С. 207; № 4. С. 118.
} 
образа врага. Как отмечает Е.Ю. Семенова, враждебное отношение к гражданскому немецкому населению выражалось в доносах, коллективных требованиях об их выселении или увольнении с работы и даже в попытках завладеть их имуществом. Однако часть населения все же сочувствовала немцам и охотно помогала им продуктами и вещами [Семенова 2011]. Репрессивная кампания, открыто развязанная правительством в отношении российских немцев, не только нарушила социально-экономический уклад регионов их компактного проживания, но крайне негативно сказалась на сплоченности общества, так необходимой в условиях войны.

Под воздействием патриотического подъема в начальный период войны начало формироваться патриотическое сознание у детей и подростков. Трагические события войны нашли живой отклик у маленьких граждан, которые также старались внести свой вклад в борьбу с противником и оказать посильную помощь пострадавшим от войны. И это проявление чувств было наиболее трогательным. Так, в одном из номеров журнала «Нива» за 1914 г. было опубликовано письмо 12-летней девочки, в котором она с детской непосредственностью обращалась к императору: «Являюсь письменно к Государю императору, чтобы помочь чемнибудь в это тяжелое время Царю, так что я будущая русско-подданная и много думаю про войну: Вот и выдумала, что если бы Ейроплан покрыть большим полотном покрашено похоже на облачко так как такой может все незаметно разузнать. Я сама хочу пойти на войну только мама говорит, что я мала мне только 12-ый год не возьмут и девочка...»1. Детское участие трогало за душу солдат, когда те получали письма с небольшими подарочками, стихотворениями и рисунками внутри от детей изо всех уголков страны.

В гимназиях ученицы специально для фронта шили постельное белье, рубашки, а в свободное время помогали сотрудникам Красного Креста в уходе за ранеными. Частым явлением среди учащихся стал сбор пожертвований на нужды фронта, причем собирали дети - кто что мог: кто копеечку, кто кусок caхара $^{2}$. Когда во многих прифронтовых городах возникла инициатива брать раненых, не требующих постоянной медицинской помощи, в семью, то зачастую именно дети уговаривали родителей на этот поступок. Конечно, сложно сказать, что ими двигало - сочувствие и желание помочь или детское любопытство, но в любом случае это был искренний порыв.

Более старших воспитанников учебных заведений местные органы власти задействовали в сельхозработах. Так, главное управление земледелия и землеустройства решило дать училищам возможность принять широкое участие в агрономической помощи крестьянским семьям, оставшимся без мужской силы, и в этих целях отменило переводные испытания, объявив, что ученики, семьи которых нуждаются в работниках, будут распущены на время весенней пахоты и сева по домам. Остальные привлекались к оказанию помощи населению окружающего училище района ${ }^{3}$.

Надо отметить, что дети крайне редко проявляли чувство ненависти к противнику. Так, по убеждению 10-летней ученицы одной из деревенских школ, «немцы и сами жалеют, что начали войну... И она готова простить им этот тяжкий грех». Многие дети откровенно жалели пленных немцев и австрийцев, считая, что они не виноваты и их заставили воевать ${ }^{4}$. Гуманистическое мировоззрение детей и подростков было своего рода индикатором моральной устойчи-

1 Письмо девочки Государю Императору. - Нива. 1914. № 42. С. 3.

2 Отношение детей к войне. - Вестник воспитания. 1915. № 2. С. 140.

3 Из деятельности правительства. - Сельскохозяйственный вестник Юго-востока. 1915. № 10. С. 14.

4 Отношение детей к войне. - Вестник воспитания. 1915. № 2. С. 155. 
вости общества, т.к. оно формировалось в процессе их воспитания взрослыми в той исторической действительности, которая их окружала.

Гуманистический порыв населения в совокупности с патриотическими настроениями, возникшими в самом начале войны, несомненно, консолидировали общество вокруг единой национальной идеи - спасения Отечества. Однако затяжной характер войны без видимых результатов создавал и на фронте, и в тылу ощущение бесполезности людских и материальных жертв. Не способствовали укреплению морального духа и внутренняя обстановка в стране, а именно ухудшение снабжения товарами первой необходимости и рост цен на продовольствие. Промышленная и торговая буржуазия продолжала получать сверхприбыли, откровенно наживаясь на нуждах граждан. Угнетающе действовали на общество и распускаемые слухи о «распутинщине», предательстве в царской семье и высшем руководстве страны. Уже к концу 1915 г. насущные проблемы населения, так и не решенные правительством, стали превалировать над патриотическими и гуманистическими настроениями. Очевидно, что падение царизма было вызвано не столько военными обстоятельствами, сколько полным разладом между властью и уставшим от тягот войны, хозяйственной разрухи и коррупции обществом. Неспособность власти грамотно использовать такие черты российского менталитета, как человечность, жертвенность, сочувствие, сопереживание, привела к тому, что гуманизм и патриотизм постепенно были вытеснены революционными идеями, приведшими Российскую империю к военному поражению и краху.

\section{Список литературы}

Белова И.Б. 2007. Военнопленные на территории Калужской и Орловской губернии в годы Первой мировой войны. - Военно-исторический жсрнал. № 12. С. 42-46.

Белова И.Б. 2011. Первая мировая война и российская провинция. 1914 - февраль 1917 г. М.: АИРО-ХХІ. 288 с.

Васильев М.В. 2014. Беженцы Первой мировой войны и Псковская губерния. Псков. № 40. С. 170-184.

Грицаева А.Н. 2008. Благотворительность в России в годы Первой мировой войны (1914 - февраль 1917 г.): опыт помощи пострадавшим от военных действий: дис. ... К.и.н. М. 289 с.

Ефимова Е.А., Захаров А.В. 2014. Правила и методы ведения войны: социально-нравственный аспект (на материалах Первой мировой войны). - Вестник Саратовского социально-экономического университета. № 4. С. 136-141.

Максимов Е.К., Тофталушин В.П. 2007. Саратовское Поволжье в годы Первой мировой войны. Саратов: Научная книга. 124 с.

Медведев В.Н. 2014. Сарепта в годы Первой мировой войны. - Военная история России: проблемы, поиски, решения: материалы международной научнопрактической конференции, посвященной 100-летию Первой мировой войны. г. Волгоград, 26-27 сентября 2014 г. Волгоград. С. 320-327.

Поршнева О.С. 2000. Менталитет и социальное поведение рабочих, крестьян и солдат России в период Первой мировой войны. дис. ... д.и.н. Екатеринбург. 359 с.

Семенова Е.Ю. 2011. Отношение горожан Поволжья к гражданскому немецкому населению в годы Первой мировой войны. - Вестник Военного универсиmema. № 1(25). C. 139-144.

Семенова Е.Ю. 2014. Взаимодействие горожан и беженцев на территории тылового города в годы Первой мировой войны (по материалам Поволжья). Известия Самарского научного иентра Российской академии наук. Т. 16. № 3(2). C. 436-443. 
Семьянинов В.П. 1914. Саратовская губерния в годы первой мировой войны. - Саратовский листок. № 11.

Холодов В.А. 2010. Первая мировая война в восприятии населения Орловской губернии (по данным орловской прессы). - Ученые записки Орловского гуманитарного университета. Сер. Гуманитарные и социальные науки. № 3. Ч. 1. C. 123-131.

DEMIDOVA Elena Igorevna, Dr.Sci. (Hist.), Head of the Chair of History, Philosophy, Political Science and Sociology, Saratov Socio-Economic Institute - branch of Plekhanov Russian University of Economics (89 Radisheva St, Saratov, Russia, 410003; demidova-elena@yandex.ru)

NAUMOV Sergei Yur'evich, Dr.Sci. (Hist.), Professor, Director of Saratov Socio-Economic Institute - branch of Plekhanov Russian University of Economics (89 Radisheva St, Saratov, Russia, 410003; rector@seun.ru)

ZAKHAROV Aleksandr Viktorovich, Dr.Sci. (Hist.), Professor of the Chair of History, Philosophy, Political Science and Sociology, Saratov Socio-Economic Institute - branch of Plekhanov Russian University of Economics (89 Radisheva St, Saratov, Russia, 410003; ZaharovAV2007@yandex.ru)

EFIMOVA Elena Aleksandrovna, Cand.Sci. (Hist.), Associate Professor of the Chair of History, Philosophy, Political Science and Sociology, Saratov Socio-Economic Institute - branch of Plekhanov Russian University of Economics (89 Radisheva St, Saratov, Russia, 410003; helenn79@mail.ru)

\section{HUMANISM AND PATRIOTISM AS FACTORS OF CONSOLIDATION OF RUSSIAN SOCIETY DURING THE FIRST WORLD WAR}

Abstract. The article is devoted to the problem of interaction between state power and society during the First World War. The article discusses the forms of manifestation of Russian patriotism and humanism, as well as the role of state and social structures in creating an atmosphere of unity and harmony inhered to the initial period of the war. The authors conclude that mental traditions formed in different population groups the need not only for performing feats at the front and rear, but also for socially useful and charitable activities.

Keywords: humanism, patriotism, First World War, consolidation of society, charity 